\title{
Swiss Direct Democracy and Regulation of Banking Sector
}

\author{
Prof. Dr. mult. Miroslaw Matyja Dr. h.c. \\ Logos International University / USA \\ Polish University Abroad in London \\ Selinus University in Bologna/Italy \\ Indian Management School and Research Centre in Mumbai/India \\ m.matyja@sunrise.ch
}

\begin{abstract}
The aim of this article is to analyze the influence of the Swiss political system on the country's banking sector. Is the Swiss direct democracy, which has no counterpart in any other country, an advantageous factor for the development and functioning of the banking sector? In order to fully answer this question, the author has analyzed the results of direct voting on the Swiss bank regulations. He has concluded that there is an important and direct influence of the political system on the functioning of the financial sector. The analysis of the results of various federal referenda confirms the thesis that the Swiss direct democracy (with its instruments of popular initiative and referendum) has a decisive influence on the regulatory process in the country's banking sector.
\end{abstract}

Keywords. Switzerland, Banking Sector, Direct Democracy, Regulation, Finance

\section{Introduction}

The Swiss political system differs significantly from other European democratic systems. Due to constitutional legislation and specific political instruments, such as referendum and popular initiative, the Swiss are really the sovereign who has the last say in every important issue from the communal to the federal level. This collective system of power, characterized by a considerable influence of various interest groups, political elites and citizens, has no counterpart in any other country. For this reason, the Swiss federalism, with its complexity and distinctiveness, cannot be directly implemented into the political system of a different country without a proper analysis of its origins and functioning.

A detailed study of the Swiss banking sector is possible only after examining the uniqueness of the country's political system, for it determines how the industry operates. It is equally important to define and systematize the methods and forms of regulation.

Can thus a proper banking regulation be established in a political system based on direct democracy? Do popular initiative and referendum, as instruments of democracy, hamper the state's policies of regulation?

It is generally known that there is a conflict of interests between democracy and the rule of law, and between the principle of democratic majority and the principle of profit maximalization that is characteristic for banks. This conflict can be managed, but it cannot be 
ultimately solved. Critics of direct democracy argue that majorities lack a sensible approach to the banking sector. Thus, when it comes to voting, they follow their particular interests rather than the sense of responsibility.

Undoubtedly, the relationship between direct democracy and the banking sector is ambivalent. Due to the instruments of direct democracy, it is much more easy for majorities in Switzerland to force through their projects than it would have been in a political system based on representation. Direct democracy is very sensitive to the preferences of the society and political elites, which means that in extreme cases it is possible to vote through a project that violates the rights of man and of the citizen.

Decision-making in representative democracy depends on political debates, arguments and, above all, with forming coalitions. Political discussion are also present in direct democracy, but there are no other mechanisms that would filter political initiatives before they are accepted by the people at the voting booths.

The influence of the Swiss direct democracy on the country's banking sector regulatory process is rarely discussed in specialist literature. Since, up to now, the problem has been mostly ignored or erroneously interpreted, it is the aim of this work to analyze it in a proper manner (Matyja, 2019).

This article presents the influence of Swiss direct democracy on the banking sector.

Essentially three referenda were scrutinized: the referendum on joining the Bretton Woods system, the referendum on capping the salaries of the banking sector managers, known also as the initiative "against rip-offs," - an example of an instrument facilitating the regulatory process, and the referendum on the so-called "Lex USA" tax deal that was rejected in the Parliament - an example of an instrument blocking the regulatory process.

\section{The Referendum on the Accession of Switzerland to the Bretton Woods Institutions}

In 1944, the United Nations Monetary and Financial Conference (also known as the Bretton Woods Conference) was held in Bretton Woods, USA, with 730 delegates from 44 Allied countries attending, culminating in the signing of the agreement.

The International Bank for Reconstruction and Development (IBRD) and the International Monetary Fund (IMF) were established to monitor and comply with the rules of the international financial system. These institutions started operating in 1946, when the agreement was ratified.

The Bretton Woods system was used to create the basis for international relations in the area of monetary system management. It was the first fully negotiable monetary system led by different governments. Each country was subject to a monetary policy obligation, one of the objectives of which was to keep exchange rates within a fluctuation band of 1 percent. The system collapsed in 1971 due to increasing burdens, and one of the main reasons for this was that the United States stopped exchanging the dollar for gold.

The International Monetary Fund is the largest financial organization in the modern world and plays an important role in the functioning of the international monetary system. Its activities can be divided into two periods. The first, from the creation of the Bretton Woods system to the suspension of the exchangeability of the US dollar for gold. It was a period of determining the rules of international monetary relations and solving international financial problems. In particular, the Fund contributed to financing markets reconstruction, balancing and reducing balance of payments deficits. The second, after August of 1971, was a period of crisis of monetary policy in the world and the search for directions of necessary reform, as 
well as a period of insufficient financial resources in the Fund. At that time, the IMF was mainly alleviating the effects of the currency crisis and the debt crisis (Matyja, 2019).

The most important tasks of this institution are as follows:

- strengthening surveillance to counter crises - the aim is to supervise the increasing flow of private capital in a globalized financial market;

- implementing international standards and codes, which should be integrated into the IMF surveillance procedures;

- liberalizing access to loans from the Fund necessary to adapt the loan structure to the requirements of international capital markets;

- protecting of the IMF's resources;

- improving the IMF's decision-making process and accountability and adapt them to the evolution of the world economy;

- promoting the participation of the private sector in crisis prevention and regulation;

- promoting of the principle of transparency and accountability of economic policy;

- strengthening national financial systems and assessing the stability of the financial sector in the member states;

- providing opportunities for debate on the foreign exchange system.

Switzerland joined the Bretton Woods institutional system after a long delay because it feared the consequences that could arise for the country due to some of the IMF's statutory provisions, including the danger of increasing internationalization of the Swiss franc due to the structurally limited balance of payments.

On the other hand, the country has opened its capital market to World Bank loans, which it could have joined much earlier if it had not been associated with simultaneous membership in the IMF. Eventually the Swiss people voted in favor of accession to the World Bank and the International Monetary Fund in a referendum on May 17, 1992. Since November of 1992, Switzerland has been officially a member of both organizations. In the referendum for accession to the Bretton Woods system, 56.4 percent voted "yes", and only 20 percent of all citizens eligible to vote took part in it (Table 1).

Table 1. Results of the referendum on Switzerland's accession to the Bretton Woods system of May 17, 1992.

\begin{tabular}{|c|c|}
\hline \multicolumn{2}{|c|}{ Number of citizens eligible to vote } \\
\hline Total & $4,516,994$ \\
\hline \multicolumn{2}{|c|}{ Number of voters } \\
\hline Votes cast & $1,753,278$ \\
\hline Percentage & 38.81 \\
\hline \multicolumn{2}{|c|}{ Number of invalid votes } \\
\hline Empty ballot papers & 101,607 \\
\hline Invalid votes & 3488 \\
\hline \multicolumn{2}{|c|}{ Number of valid votes } \\
\hline Valid votes & $1,648,183$ \\
\hline Yes & $929,929(56.4$ percent $)$ \\
\hline No & 718,254 (43.6 percent) \\
\hline
\end{tabular}

Source: Own work based on data from the Swiss Federal Statistical Office. 
Participation in the work of the IMF undoubtedly has a positive impact on the system of supervision and regulation of banks in Switzerland. Active participation in the Bretton Woods system resulted in the direct participation of Switzerland in the global financial system, and thus in the elimination of barriers to the application of regulations applied within the financial framework of the international community.

The system of direct democracy in Switzerland made it impossible for the country to join both financial organizations beforehand. This was due to the need to hold a referendum in the event of accession to both institutions, while the government was delaying accession to the World Bank due to the dependence of the Swiss franc on global financial policy. The consequence was a delayed accession to the International Monetary Fund and the lack of influence on the decisions of this organization, which are particularly severely felt in crisis periods.

\section{Referendum Against "Rip-off"}

The initiative "against rip-off" began with the collapse of Swissair, the world-famous Swiss flagship company, in 2001. Despite the bankruptcy of the airline, the then head of the company, Mario Corti, received a payout for five years in advance, unlike many Swissair suppliers who did not receive any payment for the products and services already delivered. Among them was Thomas Minder, a supplier of cosmetic products. He was also a member of the Swiss People's Party (SVP). For a long time he had been pushing for a social initiative against overcompensation of the authorities of listed companies ("gegen die Abzockerei" against rip-off), i.e., since the crisis of 2007, when it turned out that despite the poor financial performance of various listed companies, their management boards had granted themselves excessively high and economically unjustified salaries and cash prizes (Bähler, 2012). He decided to fight this type of abnormalities. By February 28, 2008, he had collected 118,583 signatures $^{1}$ on the request for a referendum on the matter. It focused on three main issues:

- excessive board salaries,

- the right of banks to vote by their representatives using shares held by other persons,

- inability of beneficiaries of insurance and pension policies (owners of deposited shares) to dispose of them during voting.

The aim of the initiative was to: introduce a ban on compensation payments to outgoing board members and advance payments to board members of listed companies for a certain period of time; ban the use of shares deposited for voting by persons who are not their owners; introduce a provision obliging pensions funds to participate in general meetings of shareholders and to vote in accordance with the wishes of their members; introduce the rule of one-year tenure - mandatory election of the president and individual members of management boards by shareholders and introduction of the possibility of remote electronic voting within the framework of the general meeting of shareholders. In order to achieve this, the initiators of the referendum proposed the inclusion of the aforementioned amendments in Article 95 of the Federal Constitution of the Swiss Confederation. ${ }^{2}$

\footnotetext{
${ }^{1}$ Initiativkomitee "gegen die Abzockerei”: Einreichung "gegen die Abzockerei," http://www.abzockerinitiativeja.ch/, accessed October 29, 2019.

${ }^{2}$ Cf. Swiss Federal Statistical Office: http://www.admin.ch/opc/de/classified-compilation/19995395/201405180000/101.pdf, accessed November 6, 2019.
} 
Minder did not agree with the suggestions of withdrawing the initiative (Teuwsen, 2013), so on March 3, 2013, a long expected referendum was held. The initiative committee had only 200,000 francs at its disposal, while its opponents, led by the financially powerful Economiesuisse, had at their disposal 8 million francs.

The supporters of Minder's initiative argued that horrendously high executive pay would be put to an end, as this issue would be decided directly by shareholders (Bühler, 2010: 247-283). Theoretically, in the most important matters for a company, including those related to remuneration, the final decision belongs to shareholders, but in practice many of them do not exercise supervision and rely in this matter on supervisory board. The composition of supervisory boards, in turn, is significantly influenced by boards of directors, especially if a given chairman has been in office for a long time. It is therefore not surprising that councils are agreeing to higher and higher salaries for the management of companies. For these reasons, in Switzerland, it is proposed to introduce additional regulations to prevent the casting of votes in order to strengthen the real shareholders, i.e., those who are actively involved in the supervision of boards of directors. In addition, the annual election of a supervisory board will strengthen shareholders' control over it and improve its work. Opponents, on the other hand, argued that the proposed initiative would not change anything with regard to the amount of management payouts, as no maximum amounts of remuneration were set. Additional rules will only unnecessarily increase bureaucracy and the annual election of a supervisory board will result in short-term decisions that will have a negative impact on the long-term health of businesses(Bühler, 2010: 247-283).

The referendum on the initiative was approved in all cantons with a national result of 68 percent on "yes" (Table 2). ${ }^{3}$ This was the third highest score in history for civic initiatives to be socially assessed in a referendum. Results above 70 percent were recorded in the following cantons: Ticino, Thurgau, Bern, Fribourg, Zürich. ${ }^{4}$ The lowest result, however, were recorded in the cantons of central Switzerland: Obwalden, Nidwalden, Zug, Appenzell Ausserrhoden, Glarus.

Econmiesuisse's arguments that the implementation of this initiative would result in the flight of large companies and financial specialists from Switzerland, which, in turn, would increase unemployment, were rejected by the public. Just before the referendum it turned out that the outgoing head of the Novartis Group, Daniel Vasella, was to receive 72 million francs on parting. This case became an additional and, perhaps, decisive argument for the opponents of the "rip-off" ban.

The citizens eligible to vote were therefore in favor of a people's initiative to impose restrictions on the remuneration of senior managers and to allow shareholders in public companies to decide on the amount of bonuses paid to managers.

Table 2. The initiative of February 26, 2008, ,, against rip-off; " results of the referendum.

\begin{tabular}{|lcc|}
\hline \multicolumn{2}{|c|}{ Number of voters } \\
\hline Eligible to vote & & $5,174,680$ \\
\hline Swiss nationals abroad & & 132,688 \\
\hline & Participation in voting & \\
\hline Votes cast & & $2,418,825$ \\
\hline
\end{tabular}

\footnotetext{
${ }^{3}$ Cf. Swiss Federal Statistical Office: http://www.bfs.admin.ch/bfs/portal/de/index/themen/17/03/blank/key/2013/012.html, accessed December 29, 2019.

${ }^{4}$ Cf. Swiss Federal Statistical Office: http://www.bfs.admin.ch/bfs/portal/de/index/themen/17/03/blank/key/2013/012.html, accessed December 29, 2019.
} 
Percentage

Valid votes

Yes

No
46.74

$2,378,159$

$1,616,184$ (68 percent)

761,975 (32 percent)

Source: Own work based on data from the Swiss Federal Statistical Office.

The main changes made after the referendum can be summarized as follows ( Bundeskanzlei, 2012):

First, the decision on the total remuneration of the management (in German "Geschäftsleitung"), the supervisory board (in German "Verwaltungsrat"), and the consultative board was granted to the general meeting of shareholders (in German "Beirat"). No physical attendance at the general meeting is now necessary to cast a vote, remote electronic voting is allowed.

Second, the annual general meeting elects the composition of supervisory boards, their chairmen, and remuneration committees.

Third, pension funds that invest in shares have to exercise their voting rights; they have to vote in the interests of their insured clients and their vote must by public.

Fourth, until that moment, institutional shareholders (and banks) had had the right to be represented by their supervisory board, but now this practice (called in German "Depotsstmirechtvertretung") is banned. Only those persons not linked to the company and elected to the general meeting are allowed to speak.

Fifth, severance pay, advances, and bonuses for the acquisition and sale of companies are now prohibited.

Six, non-compliance with the proposed changes is now punishable by imprisonment for up to three years and a fine up to six annual salaries.

It is worth noting that the European Parliament, the EU member states, and the European Commission also agreed to the compromise reached on the Capital Requirements Directive (CRD IV) and to the provision limiting bankers' bonuses. The said bonuses may not exceed annual or, in special cases, biennial income (Höltschi, 2019).

Will the adopted initiative fulfil the expectations of voters in Switzerland and be implemented in an optimal manner?

Regardless of the outcome of this referendum, it should be remembered that this decision is, above all, a clear signal to shareholders and the public. It is the responsibility of shareholders, to the state apparatus, to control the actions and remuneration of boards of directors. What is certain, however, is that the problem has been raised and has taken on a social scale.

In addition, the public authorities in Switzerland, and in particular FINMA, have unanimously supported the initiative "against rip-off". (Peyer and Schaub, 2011: 149-159).

\section{Lex USA}

In May of 2013, talks between Switzerland and the USA on disclosing to the US information on the assets of US citizens held in Swiss banks were concluded. The agreement was to make it easier for the US tax authorities to collect debts outside the country. A positive effect for Swiss banks was, among other things, to avoid high penalties for helping to evade taxes (Matyja, 2020).

It should be stressed that Swiss political and economic circles were divided in their opinions on the agreement, which contributed to the negotiation of the matter for two years. Before the text of the agreement was agreed, a dozen or so Swiss banks were being 
prosecuted in the US, where wealthy Americans were hiding their money from the tax authorities, thereby saving billions of dollars. The Switzerland-US agreement was intended to create a basis for the cancellation of these proceedings and thus to avoid gigantic penalties for the banks (Rzeczpospolita, 2013).

The pressure exerted by the American side led the Swiss not only to accept the agreement, but also to initiate appropriate changes in the banking system. According to the assumption of the authors of the agreement, the act was to regulate the rules of cooperation of banks with the US tax authorities and the rules of transferring information about clients' activities, although without disclosing their identities (Rzeczpospolita, 2013). It should be noted that the new law was intended to leave banks free to choose whether or not to comply with US requirements. A decision not to establish cooperation with the Americans meant exposing oneself to the risk of costly proceedings before American courts.

The debate on the draft of the Swiss banking system reform concerning the transfer of US banking information was initiated in June of 2013. On June 12, the Council of States rejected Lex USA by 24 votes in favor and 15 against. According to the daily Le Temps, the adoption of Lex USA by the Council of States "opened the way to the settlement of the tax conflict in the USA." (Broder I, 2013: 1). After the adoption of the law by the upper house of the Swiss parliament, it was examined by the National Council - the lower house of the parliament - which was due to give its opinion on June 18, 2018.

The vote was organized as a matter of urgency. Parliamentarians sitting in the National Council decided to reject the submitted draft. The law was rejected by a ratio of 126 to 67 . The rejection of the draft meant that Lex USA would be completely dismissed (Broder II, 2013: 1). The parliament has thus opposed the external dictate and claims of a superpower convinced of its boundless strength, and showed its neighbors that even a small state can resist (Broder II, 2013: 1).

The Swiss legislative procedure provided for a new vote by the upper house, which voted in favor of the amendments to the Swiss law in the first vote. The Council of States adopted Lex USA in the new vote. This resulted in the need for the National Council to vote again. Just like the first time, it opposed any changes to Swiss law. It should be noted that in the second vote the ratio was slightly different (123 to 63) votes, but the National Council continued to oppose the adoption of the law previously adopted by the Council of Sates.

Under the Swiss legislative procedure, all laws must be adopted in identical terms by the two chambers of the parliament. The first chamber to deal with a project is decided by the presidents of the Council of States and the National Council at a joint meeting. If one of the chambers twice rejects a law that has already been adopted by the other chamber, the legislative procedure on a given matter is brought to an end. ${ }^{5}$

Finance minister Eveline Widmer-Schlumpf encouraged the adoption of Lex USA, claiming rightly that a failure to do so would not lead to the disappearance of the "real danger" of the escalation of the tax dispute with America. In the opinion of the Swiss government, the draft bill it presented was to contribute to the creation of legal grounds for Swiss banks to avoid criminal proceedings for previous operations that had been illegal from the American point of view.

The act rejected by the National Council provided, among other things, for the possibility for banks to provide information about third parties, such as accountants or lawyers dealing with tax matters, which experts considered sufficient to identify persons

\footnotetext{
${ }^{5}$ Cf. Szwajcaria nie chce ustawy ws. przekazywania USA danych bankowych, Lex.pl, http://www.lex.pl/czytaj//artykul/szwajcaria-nie-chce-ustawy-ws-przekazywania-usa-danych-bankowych, accessed January 15, 2020.
} 
evading their obligations towards the tax authorities. Under this project, the disclosure of personal data of customers was prohibited.

The Swiss bicameral parliament (the National Council and the Council of States) is symmetrical (egalitarian) - both chambers have the same rights, their joint consent is necessary for anything to be adopted, and legislative proceedings can be initiated in each of them.

It was precisely this specific feature of the Swiss political system that led to the rejection of Lex USA in the parliament, thereby complicating and limiting the process of reforming the banking system.

\section{Conclusions}

The above examples of decisions taken in the Swiss banking sector and within the direct democracy system indicate the dysfunctionality of this form of democracy, which, like its functionality in general, is a complex and multidimensional issue.

First, although the system enables broad participation of citizens in the political life of the state, only a small minority of the society is involved. It is a minority of citizens who, regardless of a country's political system, takes or would take the political initiative and would actively participate in every decision-making process of the state. This minority is made up of political elites, the so-called "classe politique," whose opinions and views is respected by the majority of the population. Therefore, the political currents characterized as "input" are not stronger in direct democracy than in representative-parliamentary democracy.

Second, direct democracy slows down the decision-making process and thus restricts and blocks finding the desired solutions. A telling example is Switzerland's reluctance in the process of joining the Bretton Woods system. Due to the fact that many actors (political parties, interest groups, society) participate in the political process, it generates the search for compromises. On the other hand, the goal of the political elite is not to involve representatives of society in the decision-making process, but on the contrary - the elite seeks to limit the number of votes and referendums for fear of undesirable decisions at the ballot box.

Third, direct democracy weakens the position of stabilized political actors, such as the central bank, as it makes it possible to ignore the decision-making powers of state bodies. Thus, the system strengthens the role of the opposition and allows much less often than in representative parliamentary democracy to negotiate decisions in the form of discussing opposing arguments, seeking compromise, advice, and personal confrontation of political contractors. In this way, pressure groups can expose subjects that are important to their particular interests without any political responsibility. Because of this policy, interest groups are in competition with political parties between society and the state, which in turn weakens the role of the parties.

Fourth, direct democracy, with is multiplicity and diversity of decisions taken by voters, makes society politically passive. Voters are unable to keep themselves informed of all changes, which would entail too high information costs, especially when making decisions in complex matters. In Switzerland, only one sixth of voters are fully informed on the day preceding a referendum.

Fifth, a system of direct democracy may exacerbate political conflicts. This can be especially the case when a vote concerns matters characterized by "all-or-nothing" approach. It creates a risk of an escalation in the political struggle, for example, as it was the case in the vote on Lex USA.

At the same time, it must be stated that direct democracy can achieve objectives that would not be possible within a parliamentary democracy. An example of this is the 
referendum "against rip-off." It was due to the popular (civic) initiative that it was possible to politicize this social problem at all - because direct democracy, among other things, makes it easier for citizens to participate in direct political decision-making. Even non-government political actors co-decide in the political process (Möckli, 1995: 9). Moreover, direct democracy is characterized by a strong tendency to make compromises and to take public opinion into account (Möckli, 1995: 10). which was also visible during the pre-referendum campaign "against rip-off." For politicians, this means constant contact with the public for fear of an unforeseen people's initiative.

The Swiss banking sector, like any other sector of the economy, should take into account the specific nature of the political system and the instruments of direct democracy that determine the functioning of Swiss banks.

\section{References}

[1] Bähler F., Vergütungen von Verwaltungsräten und Geschäftsleitungsmitgliedern in Banken, Schulthess, Zürich 2012.

[2] Broder W. (I) La Lex USA, acte I au Conseil des Etats I, "Le Temps", June 13, 2013.

[3] Broder W. (II) La Lex USA, acte II, "Le Temps", June 19, 2013.

[4] Bühler Ch. B., Vergütungen an Verwaltung und Geschäftsleitung: Volksinitiative "gegen die Abzockerei," in: Die grosse Schweizer Aktienrevision: eine Standortbestimmung per Ende 2010, Dike, Zürich 2010.

[5] Bundeskanzlei, Volksabstimmung vom 3. März 2013 Erläuterungen des Bundesrates, November 14, 2012.

[6] Höltschi R., Eu deckelt Banker-Boni, NZZ of February 28, 2013, https://www.nzz.ch/eu-deckelt-banker-boni-1.18029975, accessed October 16, 2019.

[7] Matyja M Sektor bankowy w Polsce i w Szwajcarii. Analiza porownawcza, GlobeEdit 2020.

[8] Matyja M., The Regulatory Process of the Swiss Financial Market, LAP LAMBERT Academic 2019.

[9] Möckli S., Funktionen und Dysfunktionen der direkten Demokratie, "Beiträge und Berichte" 1995, no. 237.

[10] Peyer, P.R., Schaub R., Umsetzung des FINMA-Rundschreibens «Vergütungssysteme» bei Banken Variable Vergütungen im Spannungsfeld zwischen Regulierung und Zivilrecht, in: SJZ 2011, no. 7 (107).

[11] Rzeczpospolita: Szwajcaria przystaje na warunki USA ws. walki z unikaniem podatków, "Rzeczpospolita" Ekonomia, May 29, 2013, http://www.ekonomia.rp.pl/artykul/706164,1014551-Szwajcaria-przystaje-nawarunki-USA-ws--walki-z-unikaniem-podatkow.html?referer=redpol, accessed November15, 2019.

[12] Szwajcaria nie chce ustawy ws. przekazywania USA danych bankowych, Lex.pl, http://www.lex.pl/czytaj/-/artykul/szwajcaria-nie-chce-ustawy-ws-przekazywania-usadanych-bankowych, accessed January 15, 2020.

[13] Teuwsen, P., initiative gegen "Abzocker”. Minders Kampf, "Die Zeit”, January 24, 2013.

[14] Initiativkomitee "gegen die Abzockerei": Einreichung "gegen die Abzockerei," http://www.abzockerinitiativeja.ch/, accessed October 29, 2019.

[15] Swiss Federal Statistical Office: http://www.bfs.admin.ch/bfs/portal/de/index/themen/17/03/blank/key/2013/012.html, accessed December 29, 2019. 
Vol. 3, 1-10, February 2020

ISSN: 2668-7798

www.techniumscience.com

[16] Swiss

Federal

Statistical

Office:

https://www.bk.admin.ch/dam/bk/de/dokumente/Abstimmungsbuechlein/volksabstim mung_vom3maerz2013.pdf.download.pdf/erlaeuterungen_desbundesrates03032013.p df, p. 14-16, accessed January 12, 2020.

[17] Swiss Federal Statistical Office: http://www.admin.ch/opc/de/classifiedcompilation/19995395/201405180000/101.pdf, accessed November 6, 2019. 